\title{
UTILIZATION OF ROCKS AND ECTOMYCORRHIZAL FUNGI TO PROMOTE GROWTH OF EUCALYPT
}

\author{
Luciano Alves, Vetúria L. Oliveira*, Germano N. Silva Filho \\ Universidade Federal de Santa Catarina, Florianópolis, SC, Brasil.
}

Submitted: May 25, 2009; Approved: March 03, 2010.

\begin{abstract}
The utilization of rocks as fertilizers is limited by their low solubility. However, solubilization may be achieved by some micro-organisms, such as ectomycorrhizal fungi (ECMf). The aim of this study was to evaluate the potential of seven isolates of ECMf to solubilize two rocks, alkaline breccia and granite, and to liberate potassium and phosphorus for Eucalyptus dunnii seedlings under greenhouse conditions. Fungal inoculants were produced in a peat-vermiculite-liquid medium mixture and added to the planting substrate at $10 \%$. Rocks were ground up and added at $0.500 \mathrm{mg}$ and $16.0 \mathrm{mg}$ per plant, as a source of phosphorus and potassium, respectively. Other nutrients were added and E. dunnii seeds were sown. Control plants, non-inoculated, were fertilized with the same amount of phosphorus and potassium using soluble forms. After 90 days, the plant height, shoot dry weight, root length, phosphorus and potassium contents, and mycorrhizal colonization were evaluated. Alkaline breccia was more efficient than granite as a source of phosphorus and potassium for the plants, and may be an alternative to conventional fertilizers. Isolates UFSC-Pt22 (Pisolithus sp.) and UFSC-Pt186 (Pisolithus microcarpus) were the most efficient in promoting plant growth, mainly when combined with alkaline breccia to replace potassium and phosphorus fertilizers, respectively.
\end{abstract}

Key words: Ectomycorrhizas, inoculant, ground rock, fertilizer, Eucalyptus dunnii

\section{INTRODUCTION}

In Brazilian soils, phosphorus and potassium levels are often low, requiring the intensive application of chemical fertilizers to cultivated land and contributing to raised production costs. Increased use of fertilizers for plant production in Brazil will require the importation of more nutrient sources, in particular potassium and phosphorus sources, with a significant impact on our commercial balance. Moreover, the production of the fertilizers requires large quantities of non-renewable chemicals and high energy input mostly from petroleum-based sources. These impacts may be minimized through the application of alternative nutrient sources, such as ground rock and mining waste $(6,20)$.

Brazil has a great variety of mineral reserves that could be explored as nutrient sources for plant growth. In the state of Santa Catarina several types of alkaline rocks rich in $\mathrm{P}$ and $\mathrm{K}$ and other elements may be found (5). Ground rock may be obtained as by-products from mining activities involved in the extraction of ornamental rocks and building materials. It is easily sourced and prices are very low. It is already possible to find on the market formulations containing ground rock ready to be applied to plant growing substrates. These formulations are being used in organic agriculture to liberate macro and micro nutrients for plants.

However, the utilization of rocks as a nutrient source is

*Corresponding Author. Mailing address: Depto. de Microbiologia e Parasitologia, Centro de Ciências Biológicas, Universidade Federal de Santa Catarina, Caixa Postal 476, CEP 88040-900, Florianópolis-SC, Brazil.; Tel.: 0xx 48 3721-5166.; E-mail: veturia@ccb.ufsc.br 
limited by their low solubility, and the chemical elements present in these materials are only very slowly liberated. The availability of the nutrients in rocks may, however, be improved through the application of soil micro-organisms able to promote rock solubilization and liberate the chemical elements from them. Among these micro-organisms there are the ectomycorrhizal fungi whose efficiency in rock solubilization has already been demonstrated by several authors $(8,9,18,19,20)$.

Nevertheless, even though many ectomycorrhizal fungi are able to promote nutrient solubilization from rocks, they may differ in terms of efficiency. The fungal isolate and the type of mineral present in the rock material are among the factors that may influence the solubilization potential $(1,19,20)$.

Eucalypt, the most employed plants in Brazilian reforestation programmes, are fast growing trees that have the ability to associate with ectomycorrhizal fungi (ECMf). These reforestation programmes have to deal with low levels of soil fertility which determine that very high amounts of fertilizers are necessary to maintain the productivity at the present threshold. Fertilization alone accounts for about $38 \%$ of the costs of the applied inputs and $15 \%$ of the total costs for producing eucalypt trees (12).

In order to assure the use of rocks and inoculum in plant production programmes it is necessary to select the most efficient isolate(s) from among the ectomycorrhizal fungi capable of solubilizing the rocks or rock waste. In this context, the main objective of this work was to select ectomycorrhizal isolates able to solubilize phosphorus and potassium from two rocks representative of those found in Santa Catarina, southern Brazil.

\section{MATERIAL AND METHODS}

Seven fungal isolates, previously selected in terms of their effiency to promote growth of Eucalyptus dunnii seedlings under conventional fertilization regimes, were studied $(13,14)$. Four of the isolates were unidentified species of Pisolithus (UFSC-Pt22, UFSC-Pt26, UFSC-Pt145 and CSIRO-H1234); another isolate belonged to the species Chondrogaster angustisporus (UFSC-Ch163), and two others to Pisolithus microcarpus (UFSC-Pt186 and UFSC-Pt188).

Isolates were cultivated in solid Modified Melin-Norkrans medium (MMN), in Petri dishes and incubated for 20 days at $25 \pm 1{ }^{\circ} \mathrm{C}$. After that period, agar plugs $(8 \mathrm{~mm}$ in diameter $)$ were cut from the edges of the colonies and tested in terms of their viability and purity in culture medium of the same composition and incubated under the same temperature conditions for $48 \mathrm{~h}$. Afterwards, three plugs of each isolate were transferred to $25 \mathrm{ml}$ of liquid MMN in 250ml-erlenmeyer flasks and incubated at $25 \pm 1{ }^{\circ} \mathrm{C}$ for 21 days. Three flasks were prepared for each isolate and these cultures were employed to produce fungal inoculants.

Inoculants were prepared in $500 \mathrm{ml}$ of a peat-vermiculite mixture (1/4) (V/V) in $900 \mathrm{ml}$-flasks. The mixture had been twice sterilized at $121 \pm 1{ }^{\circ} \mathrm{C}$ for $60 \mathrm{~min}$. After sterilization, $100 \mathrm{ml}$ of liquid MMN was added to each flask followed by a new sterilization cycle of $20 \mathrm{~min}$.

Each inoculant flask received $75 \mathrm{ml}$ of a mycelial suspension produced by fragmentation of the mycelium produced in 3 erlenmeyer flasks in liquid culture medium. Fragmentation was done in a warring blender at 3,600 rpm for $5 \mathrm{~s}$. Seven days after the inoculation, inoculant cultures were supplemented with $65 \mathrm{ml}$ of liquid MMN. These flasks remained at $25 \pm 1{ }^{\circ} \mathrm{C}$ for 60 days. There were four flasks for each fungal isolate and for the control treatment, where no fungus was introduced.

Planting substrate was a sterilized mixture of peatvermiculite $(1 / 3)(\mathrm{V} / \mathrm{V})$ distributed in conical pots of $60 \mathrm{ml}$. Before inoculation, the planting substrate was fertilized with a nutrient solution in order to achieve the following proportions in mg per plant: $\mathrm{Mn}, 0.150 ; \mathrm{Mg}, 3.000 ; \mathrm{Zn}, 0.0375 ; \mathrm{Cu}, 0.125$; Mo, 0.050; B, 0.050; and Fe, 0.375. Nitrogen fertilization was portioned in five doses of $7.0 \mathrm{mg}$ per plant added every 2 weeks, beginning 2 weeks after sowing (14).

Two experiments were performed using the two rocks, alkaline breccia and granite. In one experiment, rocks were used as phosphorus (P) sources and in this case, each plant received $16.0 \mathrm{mg}$ of potassium $(\mathrm{K})$ as $\mathrm{KCl}$. In the other 
experiment, rocks were studied as K sources. In this case, each plant received $0.50 \mathrm{mg}$ of $\mathrm{P}$ as calcium phosphate $\left[\mathrm{Ca}\left(\mathrm{H}_{2} \mathrm{PO}_{4}\right)_{2} \cdot 2 \mathrm{H}_{2} \mathrm{O}\right]$.

Seeds of Eucalyptus dunnii were disinfected in ethanol $70 \%$ for $30 \mathrm{~s}$, and rinsed three times with sterilized distilled water. Afterwards, they were germinated in a solution containing boric acid $(3 \mu \mathrm{M})$, glucose $(2,0 \mathrm{~g}$ per liter) and calcium sulphate $(500 \mu \mathrm{M}), \mathrm{pH} 5.7$, under aeration (2).

Fungal inoculants were added to the planting substrate at $10 \%$ ratio $(\mathrm{V} / \mathrm{V})$. These inoculants had been previously tested in terms of viability and purity by adding samples of $1 \mathrm{~g}$ to solid MMN in Petri dishes and incubating at $25 \pm 1{ }^{\circ} \mathrm{C}$ for 4 days. The growth of a mycelium from vermiculite particles showing hyphae with the typical appearance of the isolate was considered as evidence of viability.

Before inoculation of the planting substrate, the contents of four flasks of inoculant of each isolate were mixed and homogenized and then washed lightly with 1 liter of sterilized distilled water in order to eliminate residual culture medium. For the non-inoculated control, the mixture without fungus was submitted to the same procedure. The substrate was then distributed in conical PVC pots, previously sterilized at $121 \pm 1$ ${ }^{\circ} \mathrm{C}$. In each pot, 5 seedlings were sown and the substrate was maintained at $80 \%$ of the field capacity by a daily watering with sterilized distilled water.

After three weeks, only one seedling was left in each pot. Plants were maintained in a greenhouse, where temperature varied from $18{ }^{\circ} \mathrm{C}$ (night) to $30{ }^{\circ} \mathrm{C}$ (day). Treatments were distributed according to a factorial design with two factors fungal isolates and rocks - and each combination presented five replications.

Ninety days after sowing, plants were harvested and analysed in terms of height, dry matter weight (shoot and roots), root length, mycorrhizal colonization and $\mathrm{P}$ or $\mathrm{K}$ contents of the shoots. Root systems were separated from the shoots and washed with tap water to eliminate planting substrate. A sample of $0.200 \mathrm{~g}$ fresh weight was then taken and conserved in a FAA solution (5\% of formaline, $5 \%$ acetic acid and $90 \%$ of a $50 \%$-ethanol solution). The rest of the root systems were weighed and, together with the shoots, were dried at $70 \pm 1^{\circ} \mathrm{C}$ under forced aeration and then weighed to determine plant dry matter.

Samples of $0.200 \mathrm{~g}$ of roots were randomly distributed in a 9-cm diameter Petri dish with grid lines and observed under a dissecting microscope to quantify intersections between grid lines and roots, which were designated as either colonized or non-colonized. The colonized root length and the total root length were calculated using a conversion factor based on the total length of grid lines and the area of the dish. Using a $1 / 2$ inch grid $\left(1.61 \mathrm{~cm}^{2}\right)$, the number of intersects provides the root length (colonized and non-colonized) in centimeters (4).

The phosphorus and potassium contents of the shoots were determined according to Tedesco et al. (17), using samples of $0.200 \mathrm{~g}$ of dry plant tissue.

The results were submitted to variance analysis and averages were compared by Tukey's test $(p \leq 0.05)$ using the software STATGRAPHICS Plus (Manugistics ${ }^{\circledR}$ ) for Windows ${ }^{\circledR}$. Data for the percentage of root colonization was transformed to $\sqrt{\% \text { colonization }+0.5}$ before being analysed.

\section{RESULTS}

Rocks and ectomycorrhizal fungi (ECMf), considered separately, affected $\mathrm{K}$ accumulation and plant growth (plant height, dry matter and root length) (Table 1). These two factors together had a significative effect on root length and plant $\mathrm{K}$ content.

Plants that had received $\mathrm{KCl}$, alkaline breccia and granite were taller than plants grown without potassium.

There was a positive effect of $\mathrm{KCl}$ and alkaline breccia on plant dry matter when compared to the treatment with granite and to control treatment without K. However, the two former treatments did not differ from each other, whereas plants grown with granite presented a higher dry matter weight than plants without potassium. 
Table 1. Growth, potassium (K) content and root colonization of Eucalyptus dunnii seedlings inoculated with ectomycorrhizal fungi and fertilized with different $\mathrm{K}$ sources.

\begin{tabular}{|c|c|c|c|c|c|}
\hline \multirow{2}{*}{ Isolate } & \multicolumn{4}{|c|}{ Potassium (K) source } & \multirow{2}{*}{ Average } \\
\hline & $\mathrm{KCl}$ & Alkaline breccia & Granite & Without K & \\
\hline \multicolumn{6}{|c|}{ Height $\left(\mathrm{cm} \mathrm{pl}^{-1}\right)^{(1)}$} \\
\hline Non-inoculated & $21.6 \mathrm{aA}$ & $18.1 \mathrm{aA}$ & $19.0 \mathrm{aA}$ & $15.7 \mathrm{aA}$ & $18.6 \mathrm{~b}$ \\
\hline UFSC-Pt22 & $23.9 \mathrm{aA}$ & $27.7 \mathrm{aA}$ & $24.4 \mathrm{aA}$ & $19.9 \mathrm{aA}$ & $24.0 \mathrm{a}$ \\
\hline CSIRO-H1234 & $24.3 \mathrm{aA}$ & $24.8 \mathrm{aA}$ & $24.0 \mathrm{aA}$ & $24.2 \mathrm{aA}$ & $24.3 \mathrm{a}$ \\
\hline UFSC-Pt145 & $23.2 \mathrm{aA}$ & $26.3 \mathrm{aA}$ & $24.1 \mathrm{aA}$ & $18.9 \mathrm{aA}$ & $23.1 \mathrm{a}$ \\
\hline UFSC-Pt186 & $22.8 \mathrm{aA}$ & $25.4 \mathrm{aA}$ & $23.3 \mathrm{aA}$ & $22.5 \mathrm{aA}$ & $23.5 \mathrm{a}$ \\
\hline Average & $23.2 \mathrm{~A}$ & $24.5 \mathrm{~A}$ & $23.0 \mathrm{~A}$ & $20.2 \mathrm{~B}$ & \\
\hline \multicolumn{6}{|c|}{ Total dry weight $\left(\mathrm{g} \mathrm{pl}^{-1}\right)^{(1)}$} \\
\hline Non-inoculated & $1.49 \mathrm{aA}$ & $1.27 \mathrm{aA}$ & $1.05 \mathrm{aA}$ & $0.69 \mathrm{aA}$ & $1.13 \mathrm{~b}$ \\
\hline UFSC-Pt22 & $2.26 \mathrm{aA}$ & $2.41 \mathrm{aA}$ & $1.64 \mathrm{aA}$ & $0.91 \mathrm{aA}$ & $1.80 \mathrm{a}$ \\
\hline CSIRO-H1234 & $2.17 \mathrm{aA}$ & $2.23 \mathrm{aA}$ & $1.35 \mathrm{aA}$ & $1.17 \mathrm{aA}$ & $1.73 \mathrm{a}$ \\
\hline UFSC-Pt145 & $2.38 \mathrm{aA}$ & $2.12 \mathrm{aA}$ & $1.50 \mathrm{aA}$ & $1.00 \mathrm{aA}$ & $1.75 \mathrm{a}$ \\
\hline UFSC-Pt186 & $2.12 \mathrm{aA}$ & $2.11 \mathrm{aA}$ & $1.44 \mathrm{aA}$ & $1.21 \mathrm{aA}$ & $1.72 \mathrm{a}$ \\
\hline Average & $2.08 \mathrm{~A}$ & $2.03 \mathrm{~A}$ & $1.40 \mathrm{~B}$ & $1.00 \mathrm{C}$ & \\
\hline \multicolumn{6}{|c|}{ Root length $\left(\mathrm{m} \mathrm{pl}^{-1}\right)^{(1)}$} \\
\hline Non-inoculated & $4.88 \mathrm{baA}$ & $5.46 \mathrm{bA}$ & $3.38 \mathrm{aAB}$ & $1.90 \mathrm{aB}$ & $3.91 \mathrm{~b}$ \\
\hline UFSC-Pt22 & $6.99 \mathrm{aB}$ & $11.32 \mathrm{aA}$ & $5.40 \mathrm{aBC}$ & $2.94 \mathrm{aC}$ & $6.66 \mathrm{a}$ \\
\hline CSIRO-H1234 & $7.14 \mathrm{aAB}$ & $8.73 \mathrm{abA}$ & $4.99 \mathrm{aB}$ & $3.66 \mathrm{aB}$ & $6.13 \mathrm{a}$ \\
\hline UFSC-Pt145 & $6.61 \mathrm{aAB}$ & $7.76 \mathrm{abA}$ & $4.69 \mathrm{aAB}$ & $3.18 \mathrm{aB}$ & $5.56 \mathrm{ab}$ \\
\hline UFSC-Pt186 & $6.70 \mathrm{aAB}$ & $8.70 \mathrm{abA}$ & $6.55 \mathrm{aAB}$ & $3.29 \mathrm{aB}$ & $6.31 \mathrm{a}$ \\
\hline Average & $6.46 \mathrm{~B}$ & $8.39 \mathrm{~A}$ & $5.00 \mathrm{~B}$ & $2.99 \mathrm{C}$ & \\
\hline \multicolumn{6}{|c|}{ Root colonization (\%) } \\
\hline Non-inoculated & $0 \mathrm{aA}$ & $0 \mathrm{aA}$ & $0 \mathrm{aA}$ & $0 \mathrm{aA}$ & $0 \mathrm{c}$ \\
\hline UFSC-Pt22 & $1.6 \mathrm{aA}$ & $0.6 \mathrm{aA}$ & $0.4 \mathrm{aA}$ & $1.6 \mathrm{aA}$ & $1.1 \mathrm{a}$ \\
\hline CSIRO-H1234 & $0 \mathrm{aA}$ & $0 \mathrm{aA}$ & $0 \mathrm{aA}$ & $0 \mathrm{aA}$ & $0 \mathrm{c}$ \\
\hline UFSC-Pt145 & $0 \mathrm{aA}$ & $0 \mathrm{aA}$ & $0 \mathrm{aA}$ & $0 \mathrm{aA}$ & $0 \mathrm{c}$ \\
\hline UFSC-Pt186 & $0.8 \mathrm{aA}$ & $0.4 \mathrm{aA}$ & $1.0 \mathrm{aA}$ & $0.8 \mathrm{aA}$ & $0.8 \mathrm{~b}$ \\
\hline Average & $0.5 \mathrm{~A}$ & $0.2 \mathrm{~A}$ & $0.3 \mathrm{~A}$ & $0.5 \mathrm{~A}$ & \\
\hline \multicolumn{6}{|c|}{ Shoot $\mathrm{K}$ content $\left(\mathrm{mg} \text { plant }^{-1}\right)^{(1)}$} \\
\hline Non-inoculated & $4.40 \mathrm{cA}$ & $3.00 \mathrm{aB}$ & $0.70 \mathrm{aC}$ & $0.50 \mathrm{aC}$ & $2.10 \mathrm{c}$ \\
\hline UFSC-Pt22 & $6.60 \mathrm{bA}$ & $2.60 \mathrm{aB}$ & $0.90 \mathrm{aC}$ & $1.40 \mathrm{aC}$ & $2.90 \mathrm{~b}$ \\
\hline CSIRO-H1234 & $3.70 \mathrm{cA}$ & $2.50 \mathrm{aB}$ & $1.00 \mathrm{aC}$ & $0.90 \mathrm{aC}$ & $2.00 \mathrm{c}$ \\
\hline UFSC-Pt145 & $10.0 \mathrm{aA}$ & $2.60 \mathrm{aB}$ & $1.00 \mathrm{aC}$ & $1.20 \mathrm{aC}$ & $3.70 \mathrm{a}$ \\
\hline UFSC-Pt186 & $6.00 \mathrm{bA}$ & $2.30 \mathrm{aB}$ & $1.30 \mathrm{aBC}$ & $0.70 \mathrm{aC}$ & $2.60 \mathrm{bc}$ \\
\hline Average & $6.10 \mathrm{~A}$ & $2.60 \mathrm{~B}$ & $0.90 \mathrm{C}$ & $0.90 \mathrm{C}$ & \\
\hline
\end{tabular}

Application of alkaline breccia promoted greater root length in comparison to all other fertilization treatments. Plants grown in the presence of alkaline breccia presented an increase of $30 \%, 68 \%$ and $180 \%$ in root length compared to those grown in the presence of $\mathrm{KCl}$, granite, and without potassium, respectively. Granite and $\mathrm{KCl}$ treatments were superior to the treatment without potassium in terms of root length, but were not different from each other.

Finally, there was a positive effect of $\mathrm{KCl}$ on shoot $\mathrm{K}$ content, followed by alkaline breccia, with 6.1 and $2.6 \mathrm{mg} \mathrm{K}$ per plant, respectively. There was a significant difference between the two treatments, with a higher $\mathrm{K}$ content observed in plants of the $\mathrm{KCl}$ treatment than in plants with alkaline breccia. These two treatments were, however, significantly 
superior to granite and to control without potassium, each of them presenting $0.9 \mathrm{mg} \mathrm{K}$ per plant.

Detectable root colonization was very low and colonized roots were observed only in two treatments of inoculation: UFSC-Pt22 and UFSC-Pt186. However, inoculation of the plants with ECMf promoted greater plant height and dry matter accumulation in relation to non-inoculated plants. There were not, however, any significant differences between ECMf isolates in the general average.

Plants inoculated with the isolates UFSC-Pt22, UFSCPt186 and CSIRO-H1234 had a greater root length than noninoculated plants, whereas those inoculated with the isolate UFSC-Pt145 were not significantly different to the noninoculated plants. Inoculation with the isolate UFSC-Pt22 promoted an increase of $70 \%$ compared to the non-inoculated control. These results may be responsible for the high values of height and dry matter presented by the plants under these treatments. The isolate UFSC-Pt22 promoted a higher root colonization and this may have contributed to the greater root length and, in consequence, to the elevated rate of nutrient absorption and growth.

The effect of the fECM on K shoot content was variable. Plants inoculated with the isolate UFSC-Pt145 presented the highest value, followed by plants inoculated with the isolate UFSC-Pt22. Those inoculated with the isolates CSIRO-H1234 and UFSC-Pt186 were not significantly different from noninoculated controls.

The increase of shoot $\mathrm{K}$ content promoted by the UFSCPt145 in presence of $\mathrm{KCl}$ was higher than 100\%. The combination of these two factors produced an amount of $10 \mathrm{mg}$ $\mathrm{K}$ per plant, while the non-inoculated plants fertilized with $\mathrm{KCl}$ had only $4.4 \mathrm{mg}$. This indicates that plants inoculated with this isolate recovered $60 \%$ of the $\mathrm{K}$ added to the substrate.

In combination with alkaline breccia, the isolate UFSCPt22 promoted the highest value of root length observed, which was $11.3 \mathrm{~m}$ of root per plant. This value was $30 \%$ higher than the second highest score which was obtained by the combination of the isolate CSIRO-H1234 with the same rock: $8.73 \mathrm{~m}$ per plant. Although the interaction between these two factors (rocks and ECMf) has not always been significant, the combination of the isolate UFSC-Pt22 with alkaline breccia promoted, consistently, the highest values in the majority of variables analysed, except in terms of $\mathrm{K}$ in the shoots.

The study concerning the solubilization of $\mathrm{P}$ from the two rocks showed significant effects of both rocks and fungal isolates on growth and nutrition variables. In many cases, there was also a significant interaction between these factors (Table 2). In the majority of the variables, the sources of $P$, especially alkaline breccia and calcium phosphate, promoted plant growth when compared to non-fertilized treatments. In terms of plant dry matter, alkaline breccia alone promoted an increase of $61 \%$ compared to the treatments without $\mathrm{P}$ and with granite, and of $10 \%$ in relation to calcium phosphate.

Plants fertilized with calcium phosphate presented, on average, higher amounts of $\mathrm{P}$ in their shoots when compared to those fertilized with rocks. Nevertheless, no significant differences were observed between the treatments with different $\mathrm{P}$ sources and the non-fertilized treatment.

When considered alone, inoculation with ECMf promoted a significant effect on plant growth. Inoculated plants were $30 \%$ to $15 \%$ taller than non-inoculated plants. They also presented an increase in dry matter that varied from 64 to $90 \%$ in relation to non-inoculated plants. Addition of ectomycorrhizal fungi promoted an increase in root length that varied from $63 \%$ to $75 \%$ in relation to the non-inoculated control.

Combination of the isolate UFSC-Pt186 with alkaline breccia promoted greater plant height, dry matter and root length than any other combination of fungal isolates and $\mathrm{P}$ sources.

As observed in the experiment using $\mathrm{K}$ sources, root colonization was very low. Isolates UFSC-Pt186 and UFSCPt188 colonized an average of only $0.8 \%$ and $9.4 \%$ of roots, respectively (Table 2). Plants under other treatments, including non-inoculated control, had no detectable colonization.

The highest values of $\mathrm{P}$ absorbed were observed in plants inoculated with isolate UFSC-Ch163. In the treatment without $\mathrm{P}$ fertilization, plants inoculated with this isolate presented 105 
$\mu \mathrm{g}$ P per plant. This was followed by plants inoculated with the same isolate and fertilized with alkaline breccia, presenting $87.5 \mu \mathrm{g} \mathrm{P}$ per plant. When considered alone, this fungus promoted an average of $83 \mu \mathrm{g} \mathrm{P}$ per plant, which was significantly superior to the non-inoculated treatment and to inoculation of UFSC-Pt188, where plants had an average of only 44 and $59 \mu \mathrm{g}$ P per plant, respectively.

Table 2. Growth, phosphorus (P) content and root colonization of Eucalyptus dunnii seedlings inoculated with ectomycorrhizal fungi and fertilized with different $\mathrm{P}$ sources.

\begin{tabular}{|c|c|c|c|c|c|}
\hline \multicolumn{5}{|c|}{ Phosphorus (P) source } & \multirow{2}{*}{ Average } \\
\hline Isolate & Ca phosphate & Alkaline breccia & Granite & Without P & \\
\hline \multicolumn{6}{|c|}{ Height $\left(\mathrm{cm} \mathrm{pl}^{-1}\right)^{(1)}$} \\
\hline Non-inoculated & $21.6 \mathrm{aA}$ & $23.1 \mathrm{aA}$ & $16.0 \mathrm{bB}$ & $15.5 \mathrm{cB}$ & $19.0 \mathrm{~b}$ \\
\hline UFSC-Pt26 & $24.8 \mathrm{aA}$ & $24.6 \mathrm{aA}$ & $20.3 \mathrm{abAB}$ & $18.9 \mathrm{bcB}$ & $22.1 \mathrm{a}$ \\
\hline UFSC-Ch163 & $24.8 \mathrm{aA}$ & $22.4 \mathrm{aA}$ & $23.7 \quad \mathrm{aA}$ & $22.5 \mathrm{abA}$ & $23.3 \mathrm{a}$ \\
\hline UFSC-Pt186 & $22.9 \mathrm{aA}$ & $26.0 \mathrm{aA}$ & $24.4 \quad \mathrm{aA}$ & $23.5 \mathrm{abA}$ & $24.2 \mathrm{a}$ \\
\hline UFSC-Pt188 & $23.5 \mathrm{aA}$ & $24.2 \mathrm{aA}$ & $23.9 \quad \mathrm{aA}$ & $25.6 \mathrm{aA}$ & $24.3 \mathrm{a}$ \\
\hline Average & $23.5 \mathrm{AB}$ & $24.0 \mathrm{~A}$ & $21.6 \mathrm{BC}$ & $21.2 \mathrm{C}$ & \\
\hline \multicolumn{6}{|c|}{ Total dry weight $\left(\mathrm{g} \mathrm{pl}^{-1}\right)^{(1)}$} \\
\hline Non-inoculated & $1.49 \mathrm{bA}$ & $1.90 \mathrm{bA}$ & $0.57 \mathrm{bB}$ & $0.49 \mathrm{cB}$ & $1.11 \mathrm{~b}$ \\
\hline UFSC-Pt26 & $2.21 \mathrm{aA}$ & $237 \mathrm{abA}$ & $1.40 \mathrm{aB}$ & $1.29 \mathrm{bB}$ & $1.82 \mathrm{a}$ \\
\hline UFSC-Ch163 & $2.17 \mathrm{aAB}$ & $2.27 \mathrm{abA}$ & $1.66 \mathrm{aB}$ & $1.94 \mathrm{aAB}$ & $2.01 \mathrm{a}$ \\
\hline UFSC-Pt186 & $2.12 \mathrm{aB}$ & $2.90 \mathrm{aA}$ & $1.80 \mathrm{aB}$ & $1.62 \mathrm{abB}$ & $2.11 \mathrm{a}$ \\
\hline UFSC-Pt188 & $2.42 \mathrm{aA}$ & $2.09 \mathrm{bAB}$ & $1.70 \mathrm{aB}$ & $1.79 \mathrm{abB}$ & $2.00 \mathrm{a}$ \\
\hline Average & $2.08 \mathrm{~A}$ & $2.31 \mathrm{~A}$ & $1.43 \mathrm{~B}$ & $1.43 \mathrm{~B}$ & \\
\hline \multicolumn{6}{|c|}{ Root length $\left(\mathrm{m} \mathrm{pl}^{-1}\right)^{(1)}$} \\
\hline Non-inoculated & $4.88 \mathrm{aAB}$ & $6.98 \mathrm{aA}$ & $2.36 \mathrm{bB}$ & $2.09 \mathrm{bB}$ & $4.08 \mathrm{~b}$ \\
\hline UFSC-Pt26 & $7.45 \mathrm{aA}$ & $6.26 \mathrm{aA}$ & $5.50 \mathrm{abA}$ & $5.15 \mathrm{abA}$ & $6.09 \mathrm{a}$ \\
\hline UFSC-Ch163 & $5.74 \mathrm{aA}$ & $6.56 \mathrm{aA}$ & $5.37 \mathrm{abA}$ & $7.83 \mathrm{aA}$ & $6.38 \mathrm{a}$ \\
\hline UFSC-Pt186 & $6.70 \mathrm{aA}$ & $9.14 \mathrm{aA}$ & $6.65 \mathrm{aA}$ & $6.12 \mathrm{aA}$ & $7.15 \mathrm{a}$ \\
\hline UFSC-Pt188 & $8.34 \mathrm{aA}$ & $7.57 \mathrm{aA}$ & $5.84 \mathrm{abA}$ & $6.35 \mathrm{aA}$ & $7.03 \mathrm{a}$ \\
\hline Average & $6.62 \mathrm{AB}$ & $7.30 \mathrm{~A}$ & $5.14 \mathrm{~B}$ & $5.51 \mathrm{~B}$ & \\
\hline \multicolumn{6}{|c|}{ Root colonization (\%) ${ }^{(1)}$} \\
\hline Non-inoculated & $0 \mathrm{cA}$ & $0 \mathrm{cA}$ & $0 \mathrm{cA}$ & $0 \mathrm{cA}$ & $0 \mathrm{c}$ \\
\hline UFSC-Pt26 & $0 \mathrm{cA}$ & $0 \mathrm{cA}$ & $0 \mathrm{cA}$ & $0 \mathrm{cA}$ & $0 \mathrm{c}$ \\
\hline UFSC-Ch163 & $0 \mathrm{cA}$ & $0 \mathrm{cA}$ & $0 \mathrm{cA}$ & $0 \mathrm{cA}$ & $0 \mathrm{c}$ \\
\hline UFSC-Pt186 & $0,8 \mathrm{bcA}$ & $0.8 \mathrm{bcA}$ & $0.6 \mathrm{bcA}$ & $1.0 \mathrm{bcA}$ & $0.8 \mathrm{~b}$ \\
\hline UFSC-Pt188 & $15.6 \mathrm{aA}$ & $7.0 \mathrm{aB}$ & $11.2 \mathrm{aB}$ & $3.8 \mathrm{aC}$ & $9.4 \mathrm{a}$ \\
\hline Average & $3.8 \mathrm{~A}$ & $1.6 \mathrm{AB}$ & $2.4 \mathrm{AB}$ & $0.1 \mathrm{~B}$ & \\
\hline \multicolumn{6}{|c|}{ Shoot $\mathrm{P}$ content $\left(\mu \mathrm{g} \mathrm{pl}^{-1}\right)^{(1)}$} \\
\hline Non-inoculated & $8198 \mathrm{aA}$ & $63.56 \mathrm{abA}$ & $18.20 \mathrm{bB}$ & $12.81 \mathrm{cB}$ & $44.14 \mathrm{c}$ \\
\hline UFSC-Pt26 & $62.83 \mathrm{aA}$ & $52.45 \mathrm{bcA}$ & $68.85 \mathrm{aA}$ & $58.95 \mathrm{bA}$ & $60.77 \mathrm{~b}$ \\
\hline UFSC-Ch163 & $76.36 \mathrm{aAB}$ & $87.50 \mathrm{aAB}$ & $64.03 \mathrm{aB}$ & $105.27 \mathrm{aA}$ & $83.29 \mathrm{a}$ \\
\hline UFSC-Pt186 & $71.49 \mathrm{aA}$ & $74.39 \mathrm{abA}$ & $65.84 \mathrm{aA}$ & $56.98 \mathrm{bA}$ & $67.17 \mathrm{ab}$ \\
\hline UFSC-Pt188 & $85.14 \mathrm{aA}$ & $22.59 \mathrm{cC}$ & $49.89 \mathrm{abBC}$ & $79.70 \mathrm{abAB}$ & $59.33 \mathrm{bc}$ \\
\hline Average & $75.56 \mathrm{~A}$ & $60.10 \mathrm{~B}$ & $53.36 \mathrm{~B}$ & $62.74 \mathrm{AB}$ & \\
\hline
\end{tabular}

${ }^{(1)}$ Values are the average of five replicates per treatment. Those followed by the same letter, small letters in the column and capital letters in the row, are not significantly different according to Tukey's test $(p \leq 0.05)$. 


\section{DISCUSSION}

According to the results, rocks may be an alternative source of potassium with a positive effect on plant growth and with the same level of efficiency as the conventional soluble potassium fertilizer $(\mathrm{KCl})$. However, alkaline breccia was superior in relation to granite powder. In the treatments fertilized with alkaline breccia, root length was superior even to those with $\mathrm{KCl}$. That difference did not reflect, however, on the accumulation of $\mathrm{K}$ in plant tissues, since the plants with alkaline breccia had a lower $\mathrm{K}$ content than the plants that had received $\mathrm{KCl}$.

In almost all variables analysed, there was a positive effect of the inoculation of plants with ECMf, mainly in plant height and dry matter. Dry matter was particularly high in the plants inoculated with isolate UFSC-Pt22, which promoted an increase of 60-80\% compared with non-inoculated controls.

The efficiency of this isolate (UFSC-Pt22) in promoting plant growth was intensified in the presence of alkaline breccia, but this effect seems to be independent of potassium nutrition. The K content of the plants inoculated with isolate UFSC-Pt22 was higher in the presence of soluble potassium $(\mathrm{KCl})$ than in the presence of this rock. It points towards another component of alkaline breccia that could have been better utilized by the plants in the presence of isolate UFSC-Pt22. A more detailed study of the composition of alkaline breccia may be useful to clarify that point. It is well known that ectomycorrhizal fungi may have other positive effects on their hosts besides those related to the translocation of nutrients from soil solution to the plant. One of them would be the solubilization of insoluble forms of nutrients $(10,18,19)$ or the production of plant growth-promoting substances (15).

In relation to the experiment using rocks as a $\mathrm{P}$ source, it was oberved that plants inoculated with isolates UFSC-Pt26, UFSC-Ch163 and UFSC-Pt186 presented higher shoot $\mathrm{P}$ contents in comparison with non-inoculated plants. Comparing the general averages of the inoculated treatments, plants inoculated with isolate UFSC-Ch163 presented higher $\mathrm{P}$ content in their shoots. The result indicates that isolate UFSC-
Ch163 is efficient in $\mathrm{P}$ translocation to the host as has already been observed by Souza et al. (14). Plants inoculated with the isolate UFSC-Pt188, however, were not significantly different from the non-inoculated ones.

In the cases where no $\mathrm{P}$ was added, $\mathrm{P}$ uptake by plants was significantly improved by the introduction of fungi. This observation points towards a possible mineralization of the phosphorus present in the peat by the ECMf. Such an effect may be attributed to the production of phosphatases by the fungi (16).

The fact that the inoculation with isolates UFSC-Pt26 and UFSC-Pt188 promoted growth, but did not increase P content in relation to the non-inoculated control, indicates the existence of mechanisms other than nutrient uptake involved in the positive effects of ECMf on the growth of plants (15).

The benefits promoted by the isolates that did not produce detectable levels of colonization, as was the case of the isolate UFSC-Pt145, could be the result of some kind of activity during the period of saprophytical life of the mycelium in the planting substrate. Some ECMf are able to survive saprophytically in the soil for more than 20 weeks (3). Even without colonizing the roots, they may liberate organic acids of low molecular weight which contribute to nutrient solubilization from inorganic sources already present in, or added to, the planting substrate $(7,18)$.

In a study of mycorrhizal efficiency, it was observed a similar low level of colonization of E. dunnii seedlings inoculated with the isolate UFSC-Pt188 (13). As also observed in the present study, the results of colonization did not reflect on the results of $\mathrm{P}$ accumulation in shoots $(13,14)$.

Our results indicate a low efficiency of the ectomycorrhizal isolates in solubilizing phosphorus from the sources tested. This statement is confirmed by the low level of $\mathrm{P}$ recovered from the planting substrate by the plants in relation to the amount added. The maximum value of recovery observed was $21 \%$ in the plants inoculated with the isolate UFSC-Ch163. Nevertehless, combination of certain isolates with the alkaline breccia produced a significant increase in plant growth. But if one considers the low levels of $\mathrm{P}$ in the 
granite, isolates UFSC-Ch163 and UFSC-Pt186 may be considered as having a high potential of solubilization of the chemical element from this source.

It is important to bear in mind that the results observed may not be entirely attributed to the direct nutritional effect due to a higher solubilization/uptake of the $\mathrm{P}$ or $\mathrm{K}$ present in the sources utilized by the ECMf. Niemi et al. (11) verified that the production of indol-3-acetic acid by the ectomycorrhizal fungi Pisolithus tinctorius and Paxillus involutus, and their presence in the rizosphere, stimulated the formation and growth of roots. This fact indicates that the substances liberated by the fungi were involved in the process.

Ectomycorrhizal fungi, particularly isolates UFSC-Pt22 and UFSC-Pt186, contributed to the increase of the efficiency of alkaline breccia as a source of $\mathrm{P}$ and $\mathrm{K}$ to the plants, respectively. These treatments promoted higher benefits in the growth of Eucalyptus dunnii seedlings.

According to the results, it is possible to conclude that alkaline breccia is an alternative to conventional fertilization as a source of phosphorus and potassium for Eucalyptus dunnii.

\section{ACKNOWLEDGMENTS}

This work was supported by the "Fundação de Apoio à Pesquisa Científica e Tecnológica do Estado de Santa Catarina (FAPESC)"; the authors are very grateful to "Rigesa, Celulose, Papel e Embalagens Ltda." for having kindely supplied the Eucalyptus dunnii seeds; to Mr. Robert Warren and Dr. Geoff Carr (London, U.K.) for reviewing the English expression in this manuscript.

\section{REFERENCES}

1. Andrade, L.R.M.; Martins, E.S.; Mendes, I.C. (2002). Carbonatites as a natural nutrient source for cerrado soil fertilization. 17th World Congress of Soil Science: Confronting New Realities in the 21st Century, Bangkok, Thailand, pp. 1-10.

2. Bougher, N.L.; Grove, T.S.; Malajczuk, N. (1990). Growth and phosphorus acquisition of karri (Eucalyptus diversicolor B. Muell) seedlings inoculated with ectomycorrhizal fungi in relation to phosphorus supply. New Phytol. 114 (1), 77-85.
3. Brulé, C.; Frey-Klett, P.; Pierrat, J.C.; Courrier, S.; Gérard, F.; Lemoine, M.C.; Rousselet, J.L.; Sommer, G.; Garbaye, J. (2001). Survival in the soil of the ectomycorrhizal fungus Laccaria bicolor and the effects of a mycorrhiza helper Pseudomonas fluorescens. Soil Biol. Biochem. 33 (1213), 1683-1694.

4. Brundrett, M.C.; Bougher, N.; Dell, B.; Grove, T.; Malajczuk, N. (1996). Working with mycorrhizas in forestry and agriculture, ACIAR, Canberra, Australia, $374 \mathrm{p}$.

5. Comin-Chiaramonti, P.; Gomes, C.B.; Castorina, F.; di Censi, P.; Antonini, P.; Furtado, Sandra; Ruberti, E.; Scheibe, L.F. (2002). Geochemistry and geodynamic implications of the Anitápolis and Lages alkaline-carbonatite complexes. Santa Catarina State, Brazil. Rev. Bras. Geociências, 32 (1), 43-58.

6. Harley, A.D.; Gilkes, R.J. (2000). Factors influencing the release of plant nutrient elements from silicate rock powders: a geochemical overview. Nutrient Cycling in Agroecosystems, 56, 11-36.

7. Hoffland, E.; Gorbushina, A.; Haselwandter, K.; Holmström, S.; Kuyper, T.W. Landeweert, R.; Lundström, U.; Plassard, C.; Rosling, A.; Sen, R.; Smits, M.; Van Breemen, N.; Van Hess, P.; Wallander, H. (2004). The role of fungi in weathering. Front. Ecol. Environ. 2 (5), 258-264.

8. Landeweert, R.; Finlay, R.D.; Hoffland, E.; Kuyper, T.W.; Van Breemen, N. (2001). Linking plants to rocks: ectomycorrhizal fungi mobilize nutrients from minerals. Trends Ecol. Evolut. 16 (5), 248-254.

9. Liu, Q.; Loganathan, P.; Hedley, M.J. (2005). Influence of ectomycorrhizal hyphae on phosphate fractions and dissolution of phosphate rock in rhizosphere soils of Pinus radiata. J. Plant Nutr. 28 (9), 1525-1540.

10. Mahmood, S.; Finlay, R.D.; Erland, S.; Wallander, H. (2001). Solubilization and colonisation of wood ash by ectomycorrhizal fungi isolated from a wood ash fertilised spruce forest. FEMS Microbiol. Ecol. 35 (2), 151-161.

11. Niemi, K.; Vuorinen, T.; Ernstsen, A.; Häggman, H. (2002). Ectomycorrhizal fungi and exogenous auxins influence root and mycorrhiza formation of Scots pine hypocotyl cuttings in vitro. Tree Physiol. 22 (17), 1231-1239.

12. Rodgheri, H.R. Florestas como alternativa de aumento de emprego e renda na propriedade rural. Embrapa Florestas, Circular Técnica 42, Colombo, PR, Brazil, 13p.

13. Souza, L.A.B.; Bonnassis, P.A.P.; Oliveira, V.L.; Silva Filho, G.N. (2008). New isolates of ectomycorrhizal fungi and the growth of eucalypt. Pesq. Agropec. Bras. 43 (2), 235-241.

14. Souza, L.A.B.; Oliveira, V.L.; Silva Filho, G.N. (2004). Efficiency of ectomycorrhizal fungi on phosphorus uptake and growth promoting of eucalypt. Pesq. Agropec. Bras. 39 (4), 349-355.

15. Strzelczyk, E.; Dahm, H.; Pachlewski, R.; Rozycki, H. (1997). Production of indole compounds by the ectomycorrhizal fungus Cantharellus cibarius Fr. Pedobiol. 41 (5) 402-411.

16. Tam, P.C.F.; Griffiths, D.A. (1993). Mycorrhizal associations in Hong Kong Fagaceae IV. The imobilization of organic and poorly soluble 
Alves, L. et al.

phosphates by the ectomycorrhizal fungus Pisolithus tinctorius. Mycorrhiza 2 (3), 133-139.

17. Tedesco, M.J.; Bissani, C.A.; Bohnen, H.; Gianello, C.; Volkweiss, S.J. (1995). Análise de solo, plantas e outros materiais, Editora da UFRGS, Porto Alegre, RS, Brazil, 174 p.

18. Wallander, H. (2000). Uptake of P from apatite by Pinus sylvestris seedlings colonised by different ectomycorrhizal fungi. Plant Soil 218 (1-
Rocks and ectomycorrhizas to promote growth of eucalypt

2), 249-256.

19. Wallander H.; Wickman, T. (1999). Biotite and microcline as potassium sources in ectomycorrhizal and non-mycorrhizal Pinus sylvestris seedlings. Mycorrhiza 9 (1), 25-32.

20. Yuan, L.; Huang, J.; Li, X.L.; Christie, P. (2004). Biological mobilization of potassium from clay minerals by ectomycorrhizal fungi and eucalypt seedling roots. Plant Soil 262 (1-2), 351-361. 